\title{
PARA A CRÍTICA DOS FUNDAMENTOS DA FORMAÇÃO DE PROFESSORES NO BRASIL. O PROBLEMA DA PRÁTICA [ELZA MARGARIDA DE MENDONÇA PEIXOTO]
}

\author{
DOI: https://doi.org/10.9771/gmed.v13i3.46834
}

Maria de Fátima Rodrigues Pereira ${ }^{1}$

Título: Para a crítica dos fundamentos da formação de professores no Brasil. O problema da prática Autora: Elza Margarida de Mendonça Peixoto Cidade, editora: Goiânia, Kelps; Edições Gárgula

Ano de publicação: 2021

Páginas: 252

Diz-se que uma resenha cumpre a finalidade de apresentar a obra resenhada ao leitor, e eu digo, também, de quem a escreveu, porque não deixa de ser registro do (a) autor (a) que ali deixou seu testemunho de um tema do qual se ocupou. Por isto, iniciamos com a apresentação da autora desta produção que teve nas edições Gárgula sua primeira edição.

Para o trabalho que busco, em minha memória, o que distingue a Professora Elza Margarida de Mendonça Peixoto, e, sempre me ocorre, é que estou perante uma pessoa de grande coragem, determinação e perseverança nas causas que a movem e assim a devo dar a conhecer ao leitor. Isto porque, entendo, que esse traço dá o timbre às suas ações de professora da graduação e da pós-graduação, funções que ocupa já de alguns anos para cá. Sempre a vi por inteiro nos desafios e enfrentamentos da vida, com denodo, assim, também, nas lutas teórico-práticas nas quais se inclui a pesquisa educacional.

Neste meu perscrutar ocorre-me ter lido, há pouco tempo, uma entrevista do Professor José Adriano Barata - Moura, filósofo, catedrático da Universidade de Lisboa, seu reitor no período entre 1998 a 2006, tradutor das obras de Marx e Engels para a editora Avante!, com quem Professora Elza fez um estágio de pós doutoramento entre 2014 a 2015 que auxilia neste meu afazer. Nessa entrevista, concedida ao Professores Avelino da Rosa e Antonio Francisco Lopes Dias, o filósofo afirma que muitas vezes nos centramos nas teses, concepções, ideias de um autor, e não se presta atenção na maneira como pensa. Pois é, essa determinação, coragem e perseverança que lhes falei antes, sobressai na maneira como a Professora Elza vem se colocando o desafio do como pensa e como vem galgando aquilo que sempre reportou a respeito da necessidade dela (e de todos nós) de entender e explicar o mundo e nele agir. 
Barata - Moura aponta que no "diálogo filosófico, [...], na leitura com autores com os quais nós podemos até nem ter afinidades ou simpatias" há, "sempre muito a aprender com aquilo que é a maneira como eles pensam”. Relata, a título de exemplo e bem conhece, que Marx “Quando aborda um conjunto muito amplo de questões onde os temas são outros [..] ele pensa de uma maneira dialética com fundamento ontologicamente materialista". Também Professora Elza aprendeu a pensar assim.

É, pois, neste campo do investigar materialista e dialético da história que a obra ora resenhada se coloca, ao mesmo tempo registro das trajetórias políticas e didático-pedagógicas da autora sobre as quais nos fala na Apresentação de seu livro, mas também, porque debate com aqueles que do campo marxista tem produzido suas teses, e são referência, sobre a formação de professores brasileiros, entre eles e em particular para a Educação Física, tomando como eixo a noção de prática. Nesse compromisso que se colocou, Professora Elza considera, explana e interroga as seguintes obras: Pedagogia histórico-crítica, $10^{\mathrm{a}}$ edição de 2008, de autoria do Professor Dermeval Saviani; Crítica da organização do trabalho pedagógico e da didática, também a $10^{a}$ edição que veio a lume em 2009; e Metodologia do ensino de Educação Física em suas duas edições, a $1^{\text {a }}$ de 1992 e a segunda de 2009. São estas a obras, que considera chaves, por enquanto, para a tarefa que se coloca.

Integram o livro 7 capítulos que são precedidos por Agradecimentos da autora, Nótula em Jeito de Apresentação escrita pelo Professor José Adriano Barata-Moura e Prefácio do Professor Alberto Reinaldo Reppold Filho, textos dos dois Professores com os quais fez seus estágios de pós-doutoramento.

A origem das interpelações que realiza nas obras anteriormente mencionadas vem de lá, de 1998, quando ao assumir como Professora do Curso de Licenciatura em Educação Física da Universidade Estadual de Londrina se deparou “com a contradição entre aquilo que os estudantes achavam que deveria ser a Educação Física Escolar (entre 1998 e 2011) e aquilo que eu reconhecia como necessidade formativa para preparar os professores de educação física para o ensino escolar” (PEIXOTO, 2021, p. 21).

É a perplexidade pelo desencontro prático com os seus estudantes de graduação que leva Professora Elza a penetrante estudo das obras de Marx e Engels e depois dos escritos do Professor e filósofo português que nos serviu de orientação no início desta resenha- José Adriano Barata - Moura e com ele e nas suas obras incursionar nos estudos do idealismo alemão, no pragmatismo de Dewey e Rorty, e, a modo de um reencontro com as Teses ad Feuerbach de Marx, nomeadamente a $3^{\mathrm{a}}$ - $A$ doutrina materialista de que os seres humanos são produtos das circunstâncias e da educação, [de que] seres bumanos transformados são, portanto, produtos de outras circunstâncias e de uma educação mudada, esquece que as circunstâncias são transformadas precisamente pelos seres bumanos e que o educador tem ele próprio de ser educado. Ela acaba, por isso, necessariamente, por separar a sociedade em duas partes, uma das quais fica elevada acima da sociedade (por exemplo, em Robert Owen).

A coincidência do mudar das circunstâncias e da atividade bumana só pode ser tomada e racionalmente entendida como práxis revolucionante.

Emerge desse estudo a condição para o "acerto de contas com os idealismos da prática" (PEIXOTO, 2021, p. 109) e as pedagogias que lhe são afetas, a partir da apresentação e consideração da categoria materialista da prática. 
Deste ponto, Professora Elza analisa a concepção de prática na obra - Pedagogia Histórico- Crítica e reconhece cinco núcleos de significados, aponta a necessidade de "aprofundar a elaboração teórica do significado de materialidade" (PEIXOTO, 2021, p. 154).

Nossa autora dedica-se, em seguida, à análise da obra do Professor Luiz Carlos de Freitas- Crítica da organização do trabalho pedagógico e da didática, inventaria os sentidos da categoria prática, identifica a filiação da abordagem em Marx, nomeadamente na $2^{\mathrm{a}}$ Tese ad Feuerbach, aponta a necessidade de considerar limites que possa haver quanto à concepção de objetividade a exigir estudos futuros.

No estudo que a professora Elza empreende na obra Metodologia do Ensino de Educação Física (COLETIVO DE AUTORES), também o leitor encontra um inventário de referências sobre a categoria prática, requer, também, que "Resta inalcançável, ainda que anunciada aquela dimensão de prática como transformação material, que incorpora o trabalho, o experimento e a política pensados a partir daquilo que vem sendo o trabalho pedagógico e daquilo que são as condições efetivas em que os conteúdos da cultura corporal são trabalhados na escola" (PEIXOTO, 2021, p. 201).

O livro, ora resenhado, traz resultados de trabalho realizado sobre um tema que leva em conta a complexidade das teses marxistas para a educação, aos quais nossa autora chega após mais de uma década, ao mesmo tempo aponta, ainda, a exigência de uma agenda, pela frente, para se fazer avançar a concepção materialista da categoria prática. A obra aponta para esse desafio.

Cabe, então, um convite a todas e todos que, honestamente, se interessam por entender, explicar e transformar as políticas de formação de professores em nosso país, adentremos ao texto da Professora Elza e com ela estabeleçamos o debate, sobre suas teses apresentadas em sua obra e como pensa pois, como diz o Professor Barata-Moura ao finalizar a sua Nótula em Jeito de Apresentação da obra de nossa autora: "O pensar é um ato solitário, mas nunca pensamos sozinhos. É em conjunto que fazemos a educativa descoberta do mundo e da vida"

Boa leitura!

\section{Referências:}

MARX, Karl. Teses sobre Feuerbach, 1845. Texto publicado pela primeira vez por Engels, em 1888, como apêndice à edição em livro da sua obra Ludwig Feuerbach e o Fim da Filosofia Alemã Clássica, Sttugart, 1888, pp. 69-72. Disponível em: https://www.marxists.org/portugues/marx/1845/tesfeuer.htm. Consulta em 20 de out. 2021.

OLIVEIRA, Avelino da Rosa; DIAS, Antonio Francisco Lopes Dias. Entrevista com José Barata- Moura. $\boldsymbol{O}$ material, o dialético, a ideia e a educação em Marx. In: Cadernos de Pesquisa: Pensamento Educacional. V. 9, n. 22 (2014). Disponível em https://seer.utp.br/index.php/a/issue/view/v. $\% 2009 \% 2$ C $\% 20$ n. $\% 2022 \% 20 \% 282014 \% 29$. Consulta em 20 de out. 2021.

PEIXOTO, Elza Margarida de Mendonça. Para a crítica dos fundamentos da formação de professores no Brasil. O problema da prática. Goiânia: Edições Gárgula; Kelps, 2021. 


\section{Notas}

${ }^{1}$ Doutorado em Educação pela Universidade Estadual de Campinas (Unicamp). Mestrado em Metodologia de Educação pela Universidade Estadual do Centro-Oeste em convênio com a Unicamp. Graduada em História pela Universidade de Coimbra. Professora do PPGED da Universidade Tuiuti do Paraná. Líder do Grupo de pesquisa do CNPq - Trabalho, Educação e Políticas Educacionais/Formação e Trabalho de Professores. Currículo Lattes: http://lattes.cnpq.br/9101466917000860. Orcid: https://orcid.org/0000-0002-8511-2313. E-mail: maria.pereira@,utp.br 